This is a post-peer-review, pre-copy edited version of an article published in Policy \& Politics. The definitive publisher-authenticated version Drew, J., \& Fahey, G. (2018). Framing unpopular policies and creating policy winners: the role of heresthetics, Policy \& Politics is available online at: https://

doi.org/10.1332/030557318X15241518778612 


\title{
Framing unpopular policies and creating policy winners - the role of heresthetics
}

\begin{abstract}
This article deals with a critical challenge for policymakers: how can political actors become policy winners in areas where they have previously experienced resounding losses? To address this puzzle, the article develops William Riker's concept of heresthetic, which describes how clever actors can disrupt the equilibrium of the political opposition by re-framing people's choices in such a way that they are inclined to contribute to their cause. Specifically, we propose a new analytical framework that enables scholars to trace and explain the various strategies available to politicians who seek to advance seemingly detrimental or risky policies in circumstances of uncertainty and complexity. This is applied to the surprising case of education reforms advanced by Australia's Liberal-National Coalition. In doing so, the article affirms the importance of vicarious instruction for aspiring herestheticians, the media, and the citizens that they seek to manipulate.
\end{abstract}

Keywords: Education, Reform, Australia, Rhetoric 


\section{Introduction}

Heresthetic is a neologism of the late William H Riker which seeks to explain why otherwise 'surprising political outcomes' occur (McLean, 2002, 557). The etymology of the term is the Greek haireomai which denotes 'to choose', a root which is familiar in our English word heresy ('a self-willed opinion, which is substituted for the submission to the power of truth, and leads to division and formation of sects' (Vines, 1940, 2)). Riker $(1986,8)$ notes that the word was derived from the classical Greek to emphasise that 'the Greeks should have, but did not, identify the heresthetic art'. Moreover, Riker (1986) attributes the classical Greek oversight to their preoccupation with rhetoric, which is the art of 'defining in any given case the available means of persuasion' (Aristotle, 2012, 8). Herestheticians, in contrast to rhetors, do not seek to persuade - indeed, they take preferences along dimensions (discrete ways of thinking about a problem) to be fixed. Rather, herestheticians seek to appeal to different dimensions for which preferences are in accord with their goal, or control agenda, or manipulate voting in such a way that they 'turn his (sic) prospective loss into a realised win' (Riker, 1986, 34).

Heresthetic is an important art for all political actors to master because proficiency adds a new string to one's bow. Where it is no longer tenable to suffer sustained loss on a given public policy question, and where rhetoric cannot be employed, then heresthetic may be the only option available. However, heresthetic need not be thought of only in terms of a weapon of last resort - when wielded by a master of the art it can be a devastatingly effective weapon, as the corpus of case study literature suggests. Therefore, heresthetic might also be considered as an efficacious first response for redressing areas of political disadvantage.

The purpose of this article is to assist in the development of the art by going beyond a mere recounting of heresthetic's essential elements supported by an explication of historical events, and instead developing a heuristic which can be used by putative political losers to guide decision-making in an environment characterised by uncertainty and complexity. In order to develop the heuristic, we extend the heresthetic literature through the introduction of the economic concept of opportunity cost. We first review the relative costs of rhetoric, heresthetic and simply accepting a loss on a given public policy question. We then argue against the presumption in the literature that herestheticians can constantly probe for successful manoeuvres without incurring costs. We also show why it is incorrect to consider that all heresthetic dimensions are of equal merit and stress the importance of fixing dimensionality and locking-in the win in order to avoid rhetorical and heresthetical reprisals. These various innovations provide the theoretical foundation for our heuristic which essentially depicts an 'algorithm' for examining decision making in real public policy environments.

In addition to being an important tool for prospective herestheticians, the heuristic can also be used by public policy scholars to generate and test hypotheses for ex post analysis of political surprises. To carry out such a test one requires a case study that illustrates the type of desperate predicament that might give rise to a risky heresthetical manoeuvre: A situation where political actors no longer find it tenable to continue to suffer losses on an important public policy question, but where rhetoric has largely failed to persuade. Moreover, it is important to show that voters really do care about the matter for which the heresthetic manoeuvre is directed, that 
the political actors have the capacity to ensure that the policy is carried out even if the bureaucracy opposes it, and that the political opposition represents a credible threat to the policy. The, somewhat surprising, case of Australia's Liberal-National Coalition (a conservative executive coalition) government arguing for 'fair' cuts to the funding of elite private schools fits these criteria precisely. We draw on opinion polls, details of proposed legislation and Senate composition data to show that the matter was important to voters, could be faithfully implemented by the relevant Minister despite potential bureaucratic opposition and that the legislative changes (required for implementation) might have been thwarted by the political opposition. We then formulate hypotheses drawn from the heuristic and test same against representative media artefacts (drawn from an extensive database of newspaper and online sources, classified according to (i) relevance to each hypothesis and (ii) chronology). This case study methodology is consonant with much of the 'pedagogical' narrative work on heresthetic - this is how Riker (1986) largely conceived of his seminal work, and is an approach which Iain McLean (2002) rightly lauded and others have replicated (see, for example, Rosenthal (2014); Dellepiane-Avellaneda (2012)).

The balance of this journal article is organised as follows. The next section reviews the major elements of Riker's $(1986,1996)$ heresthetic and also indicates how the literature might be extended to develop a heuristic that can guide herestheticians when making decisions with reference to the presence or absence of opportunity costs. Thereafter we describe the education funding debate in Australia and explain why it was necessary for the incumbent government to execute its heresthetic manoeuvre. Following this, we employ the aforementioned heuristic to critique the heresthetic manoeuvres of the government and political opposition, with a view to demonstrating how each party might have been more successful in 'structuring the world so that [they] could win' (Riker, 1996, 9). The concluding section presents observations on the importance of narratives regarding heresthetic for the informed operation of democracies.

\section{Literature and Development of Analytic Framework}

Riker $(1986,1996)$ asserts that heresthetic is an 'art'. If this is indeed the case, then it follows that a politician wishing to become a master heresthetician must combine a certain amount of innate talent with considerable practice. Therefore, the 'vicarious experience of instruction' (Riker, 1986, xi) takes on great importance in the development of the heresthetician suggesting that pedagogical narratives of the sort offered here can advance the state of the art considerably.

It is critical that one fully appreciates the difference between rhetoric - which seeks to persuade - and heresthetic. Rhetors seek to change people's opinions through recourse to the pathos (emotions of the listeners), logos (reasoning to prove an apparent truth) or ethos (character of the rhetor) (Aristotle, 2012). It is a 'difficult and expensive' task because it essentially requires the individual to 'acknowledge that they previously erred' (Riker, 1990, 54-5). Therefore, in order to capture an auditor's attention and provide sufficient impetus to overcome most people's reticence to admit that their opinion may have been wrong, rhetors often employ somewhat exaggerated claims of doom (for instance, Hirschman's (1991) Desperate Predicament thesis). Moreover, Riker (1990) tells us that politicians regularly face this 
imposing task (of persuading people rather than changing their product) because of constraints imposed by political ideology.

Thus, for a politician, heresthetic may offer a cost-effective alternative to achieve their goal of winning. Heresthetic takes the auditor's preferences and tastes along a particular dimension to be fixed (Nagel, 1993). Instead of attempting to persuade auditors, the heresthetician seeks to disrupt the equilibrium of the political opposition, by framing people's choices in such a way that they are inclined to contribute to their cause (Feiock et al, 2006). This disruption can be achieved by agenda control (Riker (1986) relates stories in which alternatives for voting were grouped in such a way as to defeat the Condorcet winner), strategic voting (such as votetrading) and control of dimensions (by introducing different ways of thinking about a politically contested issue in the hope of tapping into latent attitudes and thus prising off some of the dominant sect's adherents). Sometimes 'redefinition [of an issue] is rendered salient and palatable by rhetorical flavouring, but for heresthetic manoeuvres, the flavouring is only incidental' - what matters most is the framing of auditor choice (Riker, 1990, 48). In this regard, control of dimensions was the heresthetic that most intrigued Riker and represents his greatest contribution to the literature (McLean, 2002). It is also the principal subject of the lesson discussed here.

The putative political loser, who is disposed to employ dimension heresthetic, is considered to be constantly probing for 'alternative [dimensions], rejecting or exploiting them as appropriate' in an 'artistic' quest to discover the dimension that best taps into latent attitudes of auditors and hence enable a win (Riker, 1984, 15). It is argued that the putative loser has a strong incentive - and no disincentive - to keep 'prodding and poking the world' until they can structure it in such a way that they might realise a win (Shepsle, 2003, 312). However, there are constraints on this 'probing' behaviour, and moreover, not all dimensions are created equal.

The constraints come about because of opportunity costs in heresthetic interplay. Opportunity cost refers to the value of alternatives foregone and is the common way that economists conceive of cost when modelling choice behaviour with finite resources. It would also appear to be a concept of some importance to aspiring herestheticians. This is largely because 'ordinarily a single human being can simultaneously only evaluate a few issues and alternatives' (Riker, 1996, 129) - a key idea from educational psychology. Thus, in order to pursue a given dimension at a particular time, the heresthetician must necessarily forego other potentially winning dimensions. Moreover, if the pursued dimension fails to resonate strongly enough, it may be necessary to drop it in order to carve out space in the 'psyche' for the next probe. As each new dimension is introduced, time and media attention are also consumed, thus progressively adding to the total opportunity cost. This is the case not only for the issue being pursued by the heresthetician, but also with respect to other issues in the multi-dimensional political space that might have been otherwise pursued. Indeed, it would seem that not all dimensions are equal in terms of opportunity cost - dimensions that complement those that have been raised previously may add new adherents to the herestheticians' cause, without causing others who were earlier prised off from the dominant sect to reconsider their position. Therefore, a complementary dimension that is not inconsistent with previously raised 
dimensions (and can thus be simultaneously considered without giving rise to cognitive dissonance) would seem to offer an attractive proposition for herestheticians, where possible.

The method for introducing a dimension is also very important for the success of the heresthetician. In a narrative regarding the introduction of a 'camouflaged gerrymander', Riker $(1986,66)$ highlighted that introducing a new dimension may be best achieved by a politically neutral 'friend' - if the heresthetic manoeuvre is to avoid exposure by the media as a purely political ploy. The 'neutral friend' can possibly be improved upon through examining the blame game literature, specifically that relating to the power of the expert brand (Drew and Grant, 2017). Thus an 'expert neutral friend' may be an even more powerful way of introducing a new dimension. Of course, the deception inherent in employing the 'expert neutral friend' in order to enable a win is clever, but morally suspect at best; however, heresthetic, unlike its classical predecessor, has no ethos (Clingermayer, 2004). For the heresthetician, the win is everything.

To facilitate the win, timing is often of paramount importance (Dellepiane-Avellaneda, 2012). Neither community attitude nor political debate is fixed and the heresthetician must therefore be dexterous and agile (Rosenthal, 2014). Indeed, some possibilities that may be open to the heresthetician are little more than accidents in time (Rosenthal and Doron, 2009). Therefore the putative loser must be constantly alert for new opportunities to cast their opponent down and thus become the 'king of the hill' (Shepsle, 2003, 308).

When the heresthetician does manage to structure the world so that they can win, it is then important to 'play heresthetical defense' (Shepsle, 2003, p. 310). The first task to accomplish in defence of the winning position is to fix the number of dimensions in play (Nagel, 1993). In so doing, the heresthetician can prevent a dimension heresthetic reprisal. This might be achieved by dismissing attempts to introduce new dimensions as mere political games, or continuing to press the case to the media that the winning dimension is the only thing that matters. In the happiest of cases, for those required to play heresthetical defence, the winning dimension may be one that accords closely with the political opposition's ideology - thus effectively constraining the feasible set of dimensions available to them. However, the most effective way of playing heresthetical defence would seem to be to lock-in the win, made possible by restructuring the world, in such a way that it becomes irreversible (DellepianeAvellaneda, 2012). This might be achieved - at least for a time (perhaps the duration of the current parliament) - by passing Budget measures, or introducing legislation, or restructuring an institution in such a way that it is near-impossible to reverse. An irreversible win of this kind would then be impervious to not only dimension heresthetic reprisals but also broader heresthetical and rhetorical reprisals.

In this regard, Riker's (1996) last and posthumously published work, The Strategy of Rhetoric, which seeks to provide an explanation for the dynamic thematic interplay of rhetoric through what he describes as the Principles of Dispersion and Dominance, may prove instructive also for herestheticians. In this, Riker $(1996,7)$ observes that 'when one side dominates in the volume of rhetorical appeals ... the other side abandons appeals on that theme (the Dominance Principle) and when neither side dominates in volume both sides abandon it (the Dispersion 
Principle)'. These rhetoric propositions were criticised on the basis that strict adherence to the principles would result in two sides in equilibrium talking right past one another (rather than engaging in debate) with neither side having a 'rational incentive to change strategy' (McLean, 2002, 544). Moreover, it is perhaps unfortunate that the principles were couched in terms of 'themes' and 'volume', rather than applying the ideas to 'dimensions' and 'penetration', respectively. ${ }^{1}$ However, we believe that the principles - when combined with our observations on opportunity cost - can be adapted to produce a heuristic for the decision possibilities facing the dimension heresthetician, thus:

\footnotetext{
${ }^{1}$ Later in the book Riker (1996) re-formulates the principles in terms of 'issues', 'dimensions' and 'advantage'. Unfortunately, the imprecise rhetoric used in the book (which may be attributable to the posthumous organisation of his notes by others) obscures the compelling insights into the dynamics of argumentation.
} 
Figure 1. Heuristic for decision making for dimension heresthetics.

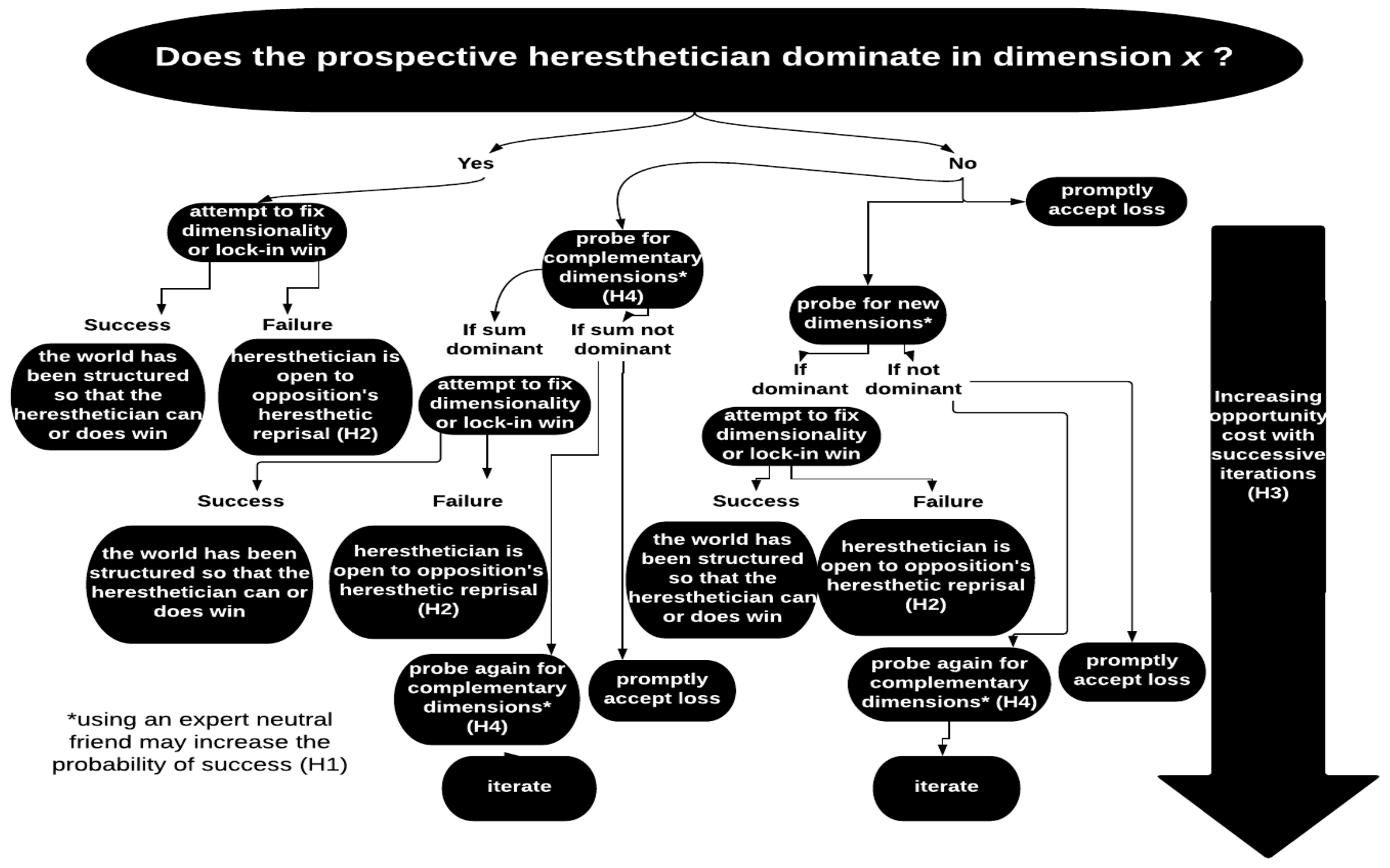


The heuristic (Figure 1) makes plain our various extensions to the literature. First, as indicated by the downwards arrow, costs accrue with each successive decision, and different decisions carry different costs. For instance, promptly accepting a loss has less opportunity costs associated with it (in terms of the value of alternatives foregone, that is, other public policy matters that the actor may have given their attention to), than trying to do just about anything else (particularly if the other options fail to achieve the heresthetician's goals). Second, the heuristic reminds prospective herestheticians that a complementary dimension has less cost associated with it than introducing an entirely new dimension (not least because some of the ground work has already been done). We also note that both complementary and new dimensions stand a higher probability of proving successful if introduced through an independent expert friend. Moreover, we make plain at various relevant points in the diagram the need to fix dimensions or lock-in the win, if dominance is achieved, in order to ensure a state whereby the heresthetician can win (because heresthetical reprisals have been prevented), or whereby the heresthetician has won (because an irreversible - at least for a time - change has been made) respectively. Finally, the heuristic operationalises an adapted version of the Dominance principle (which would see opponents abandoning the matter once the heresthetician has achieved dominance in penetration and locked-in the win) and Dispersal principle (which suggests that if either side fails to dominate then they should abandon the dimension or seek a complementary dimension).

As noted earlier, a heuristic of this kind has great potential for aspiring herestheticians because it calls to mind the opportunity costs inherent in each decision option, the importance of foiling reprisals, the superiority of complementary dimensions (should they exist), and the reality that sometimes it may be less costly to accept a loss on a particular issue and concentrate on other areas more amenable to a win. Thus the heuristic may well prove a reliable tool for more effective heresthetic manoeuvres.

In similar vein, the proposed extensions to the literature and visual representation of choices and opportunity costs in Figure 1 can help policy analysts formulate hypotheses that can then be tested in ex post analyses. For instance, the following hypotheses can be tested against the case study presented here (we have also noted the hypotheses on Figure 1):

H1: Employing an expert neutral friend will have a decisive impact on the success of a heresthetic probe

H2: Failure to fix dimensions or lock-in a win quickly may subject the proponent to reprisals.

H3: Successive probes impose opportunity costs.

H4: A complementary probe may be relatively cost-effective.

We now describe the salient aspects of the case study, before testing our analytic framework and hypotheses against representative media artefacts. 


\section{Education Funding Reform}

Australia is a federation of six states and two territories. Under the Constitution, responsibility for providing education (in both government and non-government schools) lies primarily with the states. These second-tier governments dominate the provision of compulsory education (65.4 per cent of students); however, non-government providers also play a significant role (led by the Catholic schools which educate around 20.2 per cent of students; Australian Bureau of Statistics, 2016). In terms of funding, constitutional responsibilities are set aside to some degree, with a distinction being made between government schools and the non-government sector. For government schools (which cannot compel parents to make a direct financial contribution) states and territories fund around 87.5 per cent of recurrent expenditure, and the federal government provides approximately 12.5 per cent (Australian Curriculum, Assessment and Reporting Authority (ACARA), 2017). By way of contrast, in non-government schools approximately 31.1 per cent of the funding is derived from the federal government, 11.2 per cent from states and territories and 57.7 per cent from private sources (ACARA, 2017).

Historically, conservative governments in Australia have typically championed the interests of non-government schools (recurrent funding for non-government schools was introduced nationally by the Menzies Liberal-National Coalition government in 1964), whilst the broadly social democratic Labor Party has preferenced the government sector (the Whitlam Labor government extended recurrent funding to government schools in 1974) (Parliament of Australia, 2011). Indeed, during its term in office from 2007 to 2013, Labor firmly asserted and extended its historical dominance over the Liberal-National Coalition on education policy and, in particular, school funding. In 2010, the then Labor Minister for Education announced a major review of federal education funding led by David Gonski, Chancellor of the University of New South Wales. This review recommended additional government funding in the order of 'about $\$ 5$ billion or around $15 \%$ of all government's recurrent [school] funding' per annum, with the federal government to 'bear around 30\% of the increase' (Gonski, 2011, xviii). Increased government funding for schools became the signature policy for Labor and it implemented a scheme, referred to as 'Gonski' funding, that delivered 'record levels of school funding' and ensured no school would 'lose a dollar' (Bourke, 2012) ${ }^{2}$. Despite an initial struggle to fix the quantum dimension the then Labor government eventually secured passage of the 'Gonski agreements' through the Australian Education Act 2013 - just prior to the September 2013 federal election, committing the Commonwealth to a six-year funding plan.

The matter of increased federal funding for education resonated strongly with the community and became an important campaign issue during the 2013 federal election. In order to neutralise the issue, the then opposition leader (from the Liberal Party) belatedly promised to match the incumbent's education funding commitment, and this campaign strategy played an important part in the Liberal-National Coalition gaining office (Allard, 2013). However, just months after winning government, in the May 2014 federal Budget, the Liberal-National Coalition government 'dump[ed] the Gonski school funding plan [from] 2017-18, saving around \$30

\footnotetext{
${ }^{2}$ It serves to clarify that the legislation passed by Labor (and indeed its official policy) did in fact err from the recommendations made by Gonski in his panel's 2011 review.
} 
billion from the federal Budget' arguing that it was necessary to move to 'more realistic deals' in the face of a 'budget emergency' (Griffiths, 2016). The Liberal-National Coalition's first Budget in government was widely branded as 'unfair' and this evaluation seemed to be confirmed by the (then) cross-bench senators, who blocked many of the Budget repair measures. Moreover, the plan to discontinue 'Gonski funding' led to a sustained and somewhat vitriolic campaign organised around the now infamous slogan 'I give a Gonski' by the Australian Education Union, the Labor Party and the Greens Party leading up to the subsequent July 2016 federal election. The campaign opposing cuts to the quantum of federal funding for schools contributed, in part, to a significant reduction for the Coalition majority in the House of Representatives (from fifteen to just one) and a further decrease in the Coalition minority in the Senate (with a concomitant increase in the number of cross-bench senators whose support was now required to pass legislation; ABC, 2016). It thus seemed that it was no longer tenable for the government to continue to suffer losses in the area of education policy.

Indeed, a post-election survey (Table 1) clearly showed that voters - including those who supported the governing Liberal-National Coalition - cared deeply about the government's plans to end Gonski education funding.

\section{[PLEASE INSERT TABLE 1 HERE]}

Moreover, post-election polling also showed that voters wanted the Senate to block any legislation designed to implement funding cuts (Table 2).

\section{[PLEASE INSERT TABLE 2 HERE]}

This is important because the government needed to ensure the successful passage of legislation through the Senate - the Australian Education Amendment Act 2017 - in order to amend funding arrangements. Moreover, the Liberal-National Coalition did not have a majority in the Senate (Table 3) and therefore required the support of at least nine of the cross-bench senators in order to pass the legislative amendment (in the absence of support from Labor and the Greens, which had both campaigned vigorously against plans to end Gonski funding). Passing the Bill would mean that the government would be able to overcome any bureaucratic resistance, because the governing Australian Education Act 2013 (CTH) (Section 20) confers unfettered powers to the Education Minister regarding 'amounts and timing of individual payments of financial assistance'. Thus, the government had strong incentives to execute a heresthetic manoeuvre early in 2017 so as to convert its losing political position into a winning one.

\section{[PLEASE INSERT TABLE 3 HERE]}

\section{Application of Framework}

Leading up to the 2017 Budget - the first since regaining office by the narrowest of margins in July 2016 - Prime Minister Turnbull was faced with the options that all political actors who have suffered defeat in a public policy area are presented with: (i) attempt to change auditor preferences for more funding (a rhetorical foil which, as noted above, carries relatively high 
$\operatorname{costs}^{3}$, (ii) promptly accept the loss (on education funding), (iii) introduce a new dimension, or (iv) introduce a complementary dimension (see, Figure 1). The incumbent government were not the 'king[s] of the hill' (Shepsle, 2003, 308) when it came to education funding, and, moreover, past attempts at rhetorical argumentation (based on a claim that 'the funding system was not broken' (Lane, 2013)) had largely failed to persuade (as indicated by the election result). Indeed, many commentators saw 'unfairness [as] the Coalition's kryptonite' (Keneally, 2017) whilst others recognised that 'the government had to do something on this [education] front ... that it was really being slowly killed ... since breaking its 2013 election promise [on education]' (Barnes, 2017). Therefore, promptly accepting the loss on education funding was no longer a viable alternative, implying that the government needed to execute a heresthetic manoeuvre - specifically a probe for a new dimension (given that the incumbent government really didn't have an existing dimension for which a complementary probe might be made; see, Figure 1).

The new dimension chosen by the Liberal-National Coalition - to turn a hitherto actual (not merely a potential) loss into a realised win - was 'fairness', to be achieved by pursuing 'negative funding' for elite schools (Riordan, 2017). In so doing, the Liberal-National Coalition largely turned away from overall quantum arguments (the heresthetic dimension that had been used by the political opposition with great success during the previous election campaign) and instead embraced reductions in funding for ' 24 schools in the nation's highest socioeconomic areas' from 2018 and negative growth for a 'further 335 schools ... over the next decade' (Knott, 2017). Moreover, it was asserted that these cuts would then be redistributed according to need, thus creating 'an equitable degree of opportunity for all students' (Birmingham in Van Onselen and Kennealy, 2017).

As noted in our heuristic (Figure 1) the probability of a successful probe is likely to be higher when the dimension is introduced by an expert neutral friend (H1). In this regard, the introduction of the fairness dimension is instructive, for it was made a week ahead of the 2017 May Budget by Prime Minister Turnbull and Minister Birmingham, flanked by David Gonski - the very same 'Gonski' that had been the expert independent brand endorsed by the Gillard Labor government back in 2012, and had been the rallying cry of teachers, unions and opposition political parties since the purportedly 'unfair' Budget cuts of 2014. The choice of agent (referred to in the media and by Government proponents as Gonski 2.0) came in for great praise - even from commentators who were known ideological opponents. For instance, the former Labor Premier of New South Wales applauded 'the most holy Saint David Gonski standing there next to the Prime Minister, giving Turnbull's announcement his solemn blessing' noting that 'the centre-left canonised Gonski - they can hardly complain that he's sinning against them now' (Keneally, 2017). This admiration for how the expert neutral friend was employed to introduce the dimension seems to confirm our first hypothesis that the choice of agent can have a decisive impact on the success of a heresthetic probe. Indeed, the LiberalNational Coalition appear to have improved somewhat on the 'neutral friend' of Riker's clever

\footnotetext{
${ }^{3}$ The rhetorical foil is not presented in our heuristic given that it is not a heresthetic manoeuvre.
} 
gerrymander architect, by promoting an 'expert brand' which had been previously presented as the friend of the political opposition.

The new dimension of fairness was also lauded for its capacity to resonate with an Australian voter preference for pragmatic egalitarianism and for its timing. With respect to the former, Greiner (2017) observed that the 'proposed school funding package is a model of fairness and common sense'; whilst it was noted that the timing of 'leaving such an important announcement until the week before the budget may have also been about minimising the opportunity for the government's "other" critics to re-adjust and mobilise' (Matthewson, 2017). In sum, the new dimension was declared to be 'political gold for your side' (van Onselen and Keneally, 2017) and commentators asserted that the Coalition had now 'neutralis[ed] education ... as a high point of difference between Labor and Liberal' (Waterford, 2017). It would thus seem prima facie that the Liberal-National Coalition government was now dominant in the public policy area of education funding and (as indicated by our heuristic) the time appeared ripe to lock-in the win and thus thwart opposition heresthetic and rhetorical foils.

Our second hypothesis, formulated from our extension of the heresthetic theory depicted in Figure 1, states that a failure to fix dimensions or lock-in a win may result in political actors being subject to reprisals. As noted earlier, to lock-in the win in legislation (for at least the duration of the current parliament) the Liberal-National Coalition needed to ensure successful passage of the Australian Education Amendment Act through a fractious Senate. As Table 4 details, the win was locked-in, but only after a significant delay.

\section{[PLEASE INSERT TABLE 4 HERE]}

The Budget was read in parliament on 9 May 2017 but the Australian Education Amendment Act was not passed until 22 June 2017 - over six weeks later. In sum, the win was not finalised until just over seven weeks after the new funding announcement and during this time heresthetical and rhetorical foils abounded.

The first attempt at a foil came when the (acting) Executive Director of the National Catholic Education Commission declared that 'the Turnbull government is committed to undermining our ability to provide an equitable education for families' (Cronin cited in Bye and McDougall, 2017). It seems that many of the elite schools targeted for negative growth were in the Catholic education sector. This was a rhetorical foil which sought to challenge the 'fair' cuts as being 'unfair' to families. There was also some rhetoric from conservative commentators questioning whether the policy change was consistent with Liberal Party values and constituencies - 'how many times can we attack our own people' (Bolt, 2017). This was closely followed by a heresthetical foil delivered by former Prime Minister Tony Abbot (now on the parliamentary back bench), who declared that the policy change 'certainly hasn't gone to the party room and I imagine this will be pretty vigorously debated in the party room next week' (Norman, 2017). Thus, a new dimension had been introduced - 'internal party division' on education funding. This foil received further power when Liberal senator Chris Back threatened to cross the floor if concessions were not made for the Catholic education sector (Yaxley and Borello, 2017). Meanwhile the Australian Education Union, somewhat surprisingly, vociferously opposed the 
changes, calling for negotiation and consultation - in this case the heresthetic of agenda control was being attempted (Riker, 1986).

The events which occurred during the seven weeks following the announcement seem to confirm hypothesis $\mathrm{H} 2$, that failure to fix dimensions or lock in a win quickly will open the door to reprisals. These reprisals caused the Liberal-National Coalition government to 'shovel [in] an extra \$5 billion' and the Minister to 'agree to extend existing arrangements for Catholic and independent schools for a year' (SBS, 2017). It also caused commentators to note that 'Birmingham's message has been undercut by some political clumsiness' (Crowe, 2017). Otherwise stated, the Liberal-National Coalition's failure to quickly lock-in the win may have resulted in an otherwise stunning victory being translated into a mere win.

One may question how the delay might have been mitigated in a case like this where it seems (some) negotiations needed to occur prior to the announcement of the policy, and hence prima facie before it could be known that the probe had been successful. There are two answers to this: first, the political nous which might have been expected to predict a win on 'fairness' and, second, focus groups may allow for public responses to policy innovations to be be 'pre-tested' (focus groups were seen by Riker (1986) to be a novel innovation of great potential for the heresthetician). Thus, the success of the probe might have been predicted; internal disputes within the party might have been resolved prior to the announcement, and negotiations with affected sector participants and cross-benchers might have commenced in confidence or been scheduled for the day after the announcement. By so doing, much of the negotiation might have occurred behind closed doors, and hence heresthetical and rhetorical reprisals may have been avoided.

We have thus far assessed the Liberal-National Coalition heresthetic with respect to our heuristic and the two associated hypotheses. We now turn to a critique of the social democratic (Labor) opposition response to the fairness heresthetic, in order that we might also demonstrate the relevance of the heuristic to actors wishing to fend off a heresthetic ploy. In particular, our critique of the Labor opposition response can cast light on the importance of opportunity cost (H3) and the associated relevance of complementary dimensions (H4).

On 2 May 2017 when the Liberal-National Coalition introduced the fairness dimension, our heuristic suggests that the Labor opposition was faced with much the same options that had confronted the Liberal-National Coalition in 2013 when they appeared to be trumped by the (then) Labor government's 'overall quantum' dimension: (i) attempt to change auditor preferences (a relatively costly rhetorical foil, especially in view of the constraints imposed by the Labor social democratic ideology), (ii) introduce a new dimension, (iii) introduce a complementary dimension, or (iv) accept the loss (see Figure 1).

The initial response of the Labor opposition was to attempt to dismiss the introduction of the government's fairness dimension as mere political games (unsuccessfully) through rhetoric, with 'an angry-sounding deputy Labor leader condemn[ing] what she called "an act of political bastardry" (Hewett, 2017). This was followed by the opposition leader "claim[ing] [that] $\mathrm{Mr}$ Turnbull couldn't be trusted to deliver on the Gonski 2.0 commitment' - a rhetorical foil 
offered by a putatively 'distrusted politician' that largely 'fell flat' (Matthewson, 2017). Labor also added its voice to the Catholic rhetorical challenge (detailed above).

Having failed in these rhetorical challenges (and incurred opportunity cost in the process, H3) the opposition then attempted a heresthetic foil - namely to reintroduce the quantum dimension trying to " "prove" that Turnbull's Gonski 2.0 [was] a lesser proposition, involving less money than Labor's plan' (Waterford, 2017). This is not an option included in our heuristic (Figure 1) because it does not seem particularly wise to reintroduce non-dominant heresthetic dimensions (as indicated by our adaptation of the Dispersal principle) given that the number of adherents to an existing dimension is unlikely to increase simply because it is re-introduced: Heresthetic, as denoted by its root word, is about division and formation of sects, that is, splitting people off from a winning position so that a prospective loss can be turned into a realised win. Otherwise stated, 'even the most ideologically committed [should] observe ... the futility of arguing to a stand-off' (Riker, 1996, 125).

The overall response elicited from the various rhetorical and heresthetical foil attempts made by the opposition might be best summed up by a quote which bears repeating at length: 'Labor should ... consider whether a carpet-bombing of negativity is still the most potent form of political campaigning ... it has a good chance of backfiring' (Matthewson, 2017). This statement seems to support hypothesis $\mathrm{H} 3$ that successive probes and foils incur cumulatively higher opportunity costs - in this case the combined strategy has been lumped together as a 'carpet-bombing' exercise, apparently because the auditor's capacity to simultaneously evaluate multiple issues had been exceeded. Otherwise stated, in the first instance rhetorical challenges had failed to change auditor preferences, and in the second instance re-introducing old dimensions had failed to attract additional people to the heresthetician's cause and the combined effect was to incur substantial opportunity cost. However, it is possible that the opposition might have been able to frame people's choices in such a way so as to prise off some of the dominant sect's (Liberal-National Coalition) adherents.

The most cost-effective way of doing this (as indicated in Figure 1) is to employ a complementary dimension. For instance, 'state equity' might have been pursued with vigour since there are some states that are disadvantaged by the deal (through reduction in quantum). State equity is a perennially contested issue in the Australian federation which seems to attract the attention of the media, voters and politicians. By pursuing a complementary dimension of this nature there would seem to have been a possibility of prising off some of the LiberalNational Coalition's adherents who had existing tastes for state equity. Moreover, where it could be demonstrated that states led by Liberal-National Coalition governments had been disadvantaged by the new funding deal, then there was also the possibility of creating more internal divisions in the Coalition's political ranks, particularly as senators are constitutionally conceived of as protectors of their state's interests (although voting almost always follows party lines). Some states made just such a case (notably the Coalition-led New South Wales); however, federal opposition support was both late and feeble (thus offering little support for $\mathrm{H} 4$ ), no doubt further weakened by the rising cumulative opportunity cost of earlier largely unsuccessful attacks. 
In any case, there is no certainty that adding a complementary or even a new dimension would have turned a potential loss into a realised win for the Labor opposition (therefore we can't definitively reject $\mathrm{H} 4$ ) - one would have to go back in time and play the game all over again to know such a thing (see, Riker, 1984) - but the subsequent lull in the education funding wars since the legislation was passed seems to confirm that rhetoric and old heresthetic dimensions largely failed to achieve the opposition's goal.

\section{Concluding Remarks}

We set out with a goal to draw on vicarious experience for pedagogical purposes, and it is thus incumbent upon us to summarise the main ways in which this narrative has added to the literature.

First, we have imported the economic concept of opportunity costs to argue that constraints exist on probing behaviour and to make clear that decisions faced by prospective herestheticians have inherent opportunity costs. As demonstrated from the case study, the cumulative opportunity costs increase with successive probes and can be conflated and dismissed as a carpet bombing strategy of negativity. We have also explained why rhetoric has a prima facie higher cost than heresthetic and have proposed one explanation for why politicians sometimes elect to employ a rhetorical foil despite the cost (because their ideological product traps them into a particular position - see Riker, 1990). However, much work remains to be done. For instance, we need to better understand the conditions and approach required to win on rhetoric (to complement our knowledge of how to win on heresthetic) and, in this regard, we opine that the seminal work of Hirschman (1991) may prove useful. We also need to understand whether rhetoric is always a rational choice, or whether rhetors engage without factoring in the costs and other options (such as heresthetic). Once additional questions of this type have been answered the heresthetic heuristic presented here might then be expanded to incorporate rhetorical options - thus creating a tool of even greater utility.

In addition, the analysis of Australia's education funding war has identified an improvement to Riker's (1986) 'neutral friend' detailed in the gerrymander story from his seminal work. It would seem that a 'friend' of the opposition (where possible) trumps any neutral candidate, for it is extremely difficult to attack the credibility of a person that one has previously lauded. Moreover, by drawing on the blame game literature we have also drawn attention to the relative power of an 'expert brand' friend over a mere neutral friend.

Third, the case study also demonstrates the vulnerability that the heresthetician faces with respect to heresthetic reprisals and rhetorical foils and how this might be mitigated by fixing dimensions or locking-in the win. What seems to be required here is for the heresthetician to close the sale - schmoozing is of critical importance, as has been shown, but there is an important distinction between 'structuring the world so that [they] could win' (emphasis added; Riker, 1996, 9) and actually winning. Otherwise stated, getting a person to want to buy the public policy product is not quite the same as ringing up the sale. 
In sum, the heuristic offered here accords with the heresthetic research program's aim of providing tools for more effective behaviour (Rosenthal, 2014). Moreover, as has been shown, it can be employed to generate hypotheses, which can be subsequently tested against case studies, to give rise to further insights. However, we wonder whether the articulation and extension of heresthetic literature has even wider potential applications.

For instance, it could be illuminating to examine media behaviour from the lens of heresthetic: it would seem naïve to think that the media is somehow above pursuing a heresthetic agenda. Indeed, the media selects the stories and dimensions of stories that they choose to air or print, and this paper has recounted a number of persuasive statements uttered by known conservative and social democrat commentators in the media. A study of the heresthetic of media coverage on certain events would allow us to test whether the same opportunity costs apply and whether the 'expert neutral friend' (which media seem to employ regularly) has the same decisive impact in this environment. It also seems important to understand how media behaviour can affect the outcomes of political and public policy herestheticians.

Citizens too might draw some lessons from this paper. For instance, the exposition on heresthetic might give cause for citizens to reflect on their different tastes and preferences on dimensions related to a particular political matter, and in so doing reveal that there must be some kind of internal ranking which people apply (perhaps sub-consciously) when forming or exercising a political opinion. However, beyond introspection, the heresthetic literature can remind us that politics can sometimes be about winning, rather than being moral, and that the dimension through which a political debate is being pursued is often but one way to view a given matter (that is, it is the dimension in which politicians or the media feel they can best tap into existing auditor preferences with the goal of winning voters over to their side).

In sum, this paper is therefore but a step on a much longer academic research agenda to which we hope to contribute. Well over three decades on, there is still much work to be done to bring Riker's insightful work to its full potential, and we commend this agenda to their peers. 


\section{References}

Allard, T, 2013, Surprise! Coalition backflip infuriates, 29 November 2013, The Sydney Morning Herald

Aristotle [350 BCE], 2012, The art of rhetoric, London: Collins Classics

Australian Broadcasting Commission (ABC), 2016, Election 2016: Where the parties stand on the big issues, http://www.abc.net.au/news/2016-05-13/election-2016-policy-bigissues/7387588

Australian Bureau of Statistics (ABS), 2016, Schools Australia 2016, http://www.abs.gov.au/ausstats/abs@.nsf/mf/4221.0

Australian Curriculum, Assessment and Reporting Authority (ACARA), 2017, Funding Australia's schools, http://www.acara.edu.au/reporting/national-report-on-schooling-inaustralia-2012/funding-australia-s-schools/8-4-funding-for-non-government-schools

Barnes, T, 2017, Gonski reforms a win for Turnbull? 2GB Overnight Radio Show, 21 June 2017 (M Mclaren, Interviewer)

Bolt, A, 2017, 2GB Radio Chris Smith afternoon show, 4 May 2017 (Chris Smith, Interviewer)

Bourke, C, 2012, Legislative Assembly for the ACT, 24 August 2012, Hansard, Australian Capital Territory

Bye, C, McDougall, B, 2017, Catholic education will fight Gonski 2.0 if it results in children leaving their system due to cost, 3 May 2017, Daily Telegraph

Clingermayer, J, 2004, Heresthetics and happenstance: Intentional and unintentional exclusionary impacts of the zoning decision-making process, Urban Studies, 41, 2, 377-88

Crowe, D, 2017, Libs must hold their nerves to push through Gonski 2.0, 5 May 2017, The Australian

Dellepiane-Avellaneda, S, 2012, Gordon unbound: The heresthetic of central bank independence in Britain, British Journal of Political Science, 43, 263-93

Drew, J, Grant, B, 2017, Multiple agents, blame games and public policy-making: The case of local government reform in New South Wales, Australian Journal of Political Science, 52, 1, $37-52$

Essential Research, 2016, Gonski education funding: Essential Report, 6 December 2016, Essential Media: Sydney

Feiock, R, Carr, J, Johnson, L, 2006, Structuring the debate on consolidation: A response to Leland and Thurmaier. Public Administration Review, March/April, 274-8

Gonski, D, 2011, Review of funding for schooling: Final report. Canberra: Australian Government 
Greiner, N, 2017, Fair and rational school funding system long overdue, 5 May 2017, The Australian

Griffiths, E, 2016, Budget 2014: No pain, no gain as Treasurer Joe Hockey slashes spending in 'budget repair' job, Australian Broadcasting Commission (ABC), http://www.abc.net.au/news/2014-05-13/budget-2014-joe-hockey-slashes-spending-inbudget-repair-job/5446700

Hirschman, A, 1991, The rhetoric of reaction: Perversity, futility, jeopardy, Cambridge: Belknap Press of Harvard University Press

Hewett, J, 2017, Turnbull co-opts Gonski, costs Labor, 2 May 2017, Australian Financial Review

Keneally, K, 2017, Malcolm 2.0 is all about fairness. He's not fooling anyone, 4 May 2017, The Guardian

Knott, M, 2017, Schools funding: Malcolm Turnbull dubs new \$19b education policy Gonski 2.0, The Sydney Morning Herald, http://www.smh.com.au/federal-politics/politicalnews/schools-funding-malcolm-turnbull-dubs-new-19b-deal-gonski-20-20170502gvx6a6.html

Lane, S, 2013, Education policy: where the parties stand, 5 August 2013, ABC News

Matthewson, P, 2017, Labor's response to Gonski 2.0 hasn't made the grade, except to bare its weakness, 5 May 2017, The New Daily

McLean, I, 2002, William H. Riker and the invention of heresthetic(s), British Journal of Political Science, 32, 3, 535-58

Nagel, J, 1993, Heresthetics and political stability: Richard Seddon and the art of majority rule, British Journal of Political Science, 23, 2, 139-74

Norman, J, 2017, Gonski 2.0 to be vigorously debated, Tony Abbot warns Prime Minister, ABC, http://www.abc.net.au/news/story-streams/federal-budget-2017/2017-05-03/gonski-2.0to-be-vigorously-debated,-abbott-warns-turnbull/8494952

Parliament of Australia, 2011, Australian Government funding for schools explained, Canberra: Parliamentary Library

ReachTEL, 2016, TAI National Opinion Poll 4 July 2016, South Brisbane: ReachTEL Pty Ltd Riker, WH, 1984, The heresthetics of constitution-making: The presidency in 1787, with comments on determinism and rational choice, The American Political Science Review, 78, 116.

Riker, WH, 1986, The art of political manipulation, New Haven: Yale University Press 
Riker, WH, 1990, Heresthetic and rhetoric in the spatial model, in J Enelow and M Hinich (eds), Advances in the spatial theory of voting, New York: Cambridge University Press, 46-65

Riker, WH, 1996, The Strategy of rhetoric: Campaigning for the American constitution, New Haven: Yale University Press

Riordan, P, 2017, The overfunded schools in PM's sights, 3 May 2017, The Australian

Rosenthal, M, 2014, Policy instability in a comparative perspective: The context of heresthetic, Political Studies, 62, 172-96

Rosenthal, M, Doron, G, 2009, Israel's 1993 decision to make peace with the PLO and how political losers (this time) became winners, International Negotiation, 14, 449-74

Shepsle, K. 2003. Losers in politics (and how they sometimes become winners). Perspectives on Politics, 1, 2, 307-15

Special Broadcasting Service (SBS), 2017, Gonski 2.0 passes in early hours with crossbench support. http://www.sbs.com.au/news/article/2017/06/23/gonski-20-passes-early-hourscrossbench-support

Van Onselen, P, Keneally, K, 2017, Interview on Sky News, To the point with Kristina Keneally and Peter Van Onselen, 3 May 2017, (S Birmingham, Interviewee)

Vines, WE, 1940, Vine's expository dictionary, Virginia: Mac Donald

Waterford, J, 2017, Gonski 2.0 ingredients need a recipe, 6 May 2017, The Sydney Morning Herald

Yaxley, L, Borello, E, 2017, Gonski 2.0: Liberal senator threatens to cross floor on government's school funding bill. ABC, http://www.abc.net.au/news/2017-06-19/gonskigovernment-lobbying-hard-to-get-package-passed/8629174 
Table 1: Poll of Voter Preferences Regarding Education Funding, 6 December 2016

Question: 'The Federal Government is proposing to end Gonski needs-based funding after 2017 and introduce a new funding system which would leave schools \$3.8 billion worse off in 2018 and 2019 alone. Do you approve or disapprove of this decision?'

\begin{tabular}{cccccc}
\hline & Total & Labor Voters & $\begin{array}{c}\text { Liberal/National } \\
\text { Voters }\end{array}$ & $\begin{array}{c}\text { Greens } \\
\text { Voters }\end{array}$ & Other Voters \\
\hline $\begin{array}{c}\text { Total approve } \\
\begin{array}{c}\text { Total } \\
\text { disapprove }\end{array}\end{array}$ & $18 \%$ & $11 \%$ & $33 \%$ & $11 \%$ & $15 \%$ \\
Undecided & $54 \%$ & $73 \%$ & $35 \%$ & $70 \%$ & $60 \%$ \\
\hline
\end{tabular}

Source: Essential Research (2016)

Table 2: Poll of Voter Preference for Senate Deliberations on Education Funding, 4 July 2016

Question: 'Do you think the Senate should vote to keep the Gonski needs-based funding for schools?'

\begin{tabular}{cccccc}
\hline & Total & Labor Voters & $\begin{array}{c}\text { Liberal/National } \\
\text { Voters }\end{array}$ & $\begin{array}{c}\text { Greens } \\
\text { Voters }\end{array}$ & Other Voters \\
\hline $\begin{array}{c}\text { Vote to keep } \\
\text { spending }\end{array}$ & $64.0 \%$ & $84.9 \%$ & $37.9 \%$ & $94.1 \%$ & $68.1 \%$ \\
$\begin{array}{c}\text { Vote to cut } \\
\text { spending }\end{array}$ & $23.3 \%$ & $5.9 \%$ & $44.1 \%$ & $3.6 \%$ & $18.5 \%$ \\
Undecided & $12.7 \%$ & $9.3 \%$ & $18.0 \%$ & $2.3 \%$ & $13.4 \%$ \\
\hline
\end{tabular}

Source: ReachTEL (2016)

Table 3: Composition of the Senate for the 45th Parliament of the Commonwealth of Australia (as at May, 2017)

\begin{tabular}{lccccc}
\hline & \multicolumn{2}{c}{ Government } & \multicolumn{2}{c}{ Opposition } & Crossbench \\
\hline & Liberal & National & Labor & Greens & Minority \\
\hline Seats in Senate & 25 & 5 & 26 & 9 & 11 \\
\hline
\end{tabular}


Table 4: Voting Division Parliament of the Commonwealth of Australia Senate, Australian Education Amendment Act, 22 June 2017

\begin{tabular}{ccccccc}
\hline & \multicolumn{2}{c}{ Government } & \multicolumn{2}{c}{ Opposition } & \multicolumn{2}{c}{ Crossbench } \\
\hline & Liberal & National & Labor & Greens & Independent & Minority \\
\hline Seats in Senate & 24 & 5 & 26 & 9 & 1 & 11 \\
Absent & 4 & - & 5 & - & - & 2 \\
Voting & 20 & 5 & 21 & 9 & 1 & 9 \\
\hline Votes in favour of bill & 20 & 5 & - & - & 1 & 8 \\
\hline Votes against the bill & - & - & 21 & 9 & - & 1 \\
\hline
\end{tabular}

